\title{
Solution to the beryllium valence challenge
}

\author{
Juris Meija
}

Published online: 19 March 2010

(C) Crown copyright in right of Canada 2010

\section{Solution}

The quest in this column is to elucidate the valence of beryllium from the density measurements of the soluble chlorides, as suggested by Mendeleyev in 1889 [1, 2]. From the composition of beryllium oxide we gather that the atomic weight of beryllium is either 9 or $13.5 \mathrm{Da}$, depending on the valence of beryllium, or simply $4.5 x \mathrm{Da}$ where $x$ is the valence [2]. Now, it is known that solutions of beryllium chloride, prepared by dissolving $2.00 \mathrm{~g}$ and $3.00 \mathrm{~g}$ anhydrous salt in $90.0 \mathrm{~g}$ water, have densities 1.0138 and $1.0211 \mathrm{~g} \mathrm{~mL}^{-1}$, respectively at $15^{\circ} \mathrm{C}$. Because dilute equimolar solutions of metal chlorides will have densities increasing in the order of their molecular weights it is necessary to calculate the amount of beryllium chloride in these two solutions:

$n_{1}\left(\mathrm{BeCl}_{x}\right)=\frac{2.00 \mathrm{~g}}{(4.5 x+35.5 x) \mathrm{g} \mathrm{mol}^{-1}}=0.050 \cdot x^{-1} \mathrm{~mol}$,
$n_{2}\left(\mathrm{BeCl}_{x}\right)=\frac{3.00 \mathrm{~g} \mathrm{~g}^{-1}}{(4.5 x+35.5 x) \mathrm{g} \mathrm{mol}^{-}}=0.075 \cdot x^{-1} \mathrm{~mol}$.

This article is the solution to the Analytical Challenge to be found at http://dx.doi.org/10.1007/s00216-009-3241-7

J. Meija $(\varangle)$

Institute for National Measurement Standards,

National Research Council Canada,

1200 Montreal Road,

Ottawa, ON K1A 0R6, Canada

e-mail: juris.meija@nrc.ca
In both cases the amount of water is $90.0 \mathrm{~g} / 18.0 \mathrm{~g}$ $\mathrm{mol}^{-1}=5.00 \mathrm{~mol}$. If $x=2$, the first solution has $200 \mathrm{~mol}$ water per mol $\mathrm{BeCl}_{2}$. If, however, $x=3$, the second solution has exactly $200 \mathrm{~mol}$ water per $\mathrm{mol} \mathrm{BeCl}_{3}$. Now we need to compare the densities of these solutions with those of $\mathrm{KCl}(M=75), \mathrm{MgCl}_{2}(M=93), \mathrm{CaCl}_{2}(M=111)$, and $\mathrm{MnCl}_{2}$ ( $M=126)$, all containing $200 \mathrm{~mol}(3600 \mathrm{~g}$ ) water per mol salt. The mass fraction of chlorides in such solutions is:

$w(\mathrm{KCl})=\frac{75 \mathrm{~g}}{3600 \mathrm{~g}+75 \mathrm{~g}}=2.0 \%, \quad w\left(\mathrm{MgCl}_{2}\right)=\frac{93 \mathrm{~g}}{3600 \mathrm{~g}+93 \mathrm{~g}}=2.5 \%$,
$w\left(\mathrm{CaCl}_{2}\right)=\frac{111 \mathrm{~g}}{3600 \mathrm{~g}+111 \mathrm{~g}}=3.0 \%, \quad w\left(\mathrm{MnCl}_{2}\right)=\frac{126 \mathrm{~g}}{3600 \mathrm{~g}+126 \mathrm{~g}}=3.4 \%$.

The densities of these solutions $\left(15^{\circ} \mathrm{C}\right)$ can be obtained from chemistry handbooks, and are 1.012, 1.020, 1.024, and $1.029 \mathrm{~g} \mathrm{~mL}^{-1}$, respectively. If beryllium is divalent $\left(\mathrm{BeCl}_{2}, M=80\right)$, the density of $\mathrm{BeCl}_{2}$ solution with $n\left(\mathrm{H}_{2} \mathrm{O}\right)$ : $n\left(\mathrm{BeCl}_{2}\right)=200: 1$ must be slightly above that of $\mathrm{KCl}$ yet below that of $\mathrm{MgCl}_{2}$ - which is the case. Alternatively, for trivalent beryllium $\left(\mathrm{BeCl}_{3}, M=120\right)$ the density of its chloride solution must be above that of $\mathrm{CaCl}_{2}$ - which is not the case. Thus, density measurements of aqueous chlorides are (correctly) in support of divalent beryllium.

\section{References}

1. Mendeleev D (1889) J Chem Soc 55:634-656

2. Meija J (2010) Anal Bioanal Chem 396:185-186 